\title{
Reproductive and Developmental Effects of Moxifloxacin on Female Mice and Embryos
}

\author{
Hanaa M. Roshdy \\ Cell Biology Department, National Research Center \\ Dokki, Cairo, Egypt
}

\begin{abstract}
Moxifloxacin (Avelox ${ }^{\circledR}$ ) is a fluoroquinolone antibiotic with a broad spectrum of activity and bactericidal action. Moxifloxacin has in vitro activity against a wide range of Grampositive and Gram-negative organisms. The safe use of moxifloxacin in human pregnancy has not been established. In order to evaluate the genotoxic and embryo toxic effects of (Avelox) ${ }^{\circledR}$ during pregnancy, Avelox was administrated orally to female mice with doses (8.7, 17 and 26 $\mathrm{mg} / \mathrm{kg} /$ day) from 1 to 17 days of pregnancy. Caesarean sections were completed on gestation day 18 and complete fetal examinations and cytogenetic analysis were conducted. Decreases in the fetal body weights and increases in the external visceral and skeletal anomalies were found in all doses of $(8.7,17$ and $26 \mathrm{mg}$ ) Avelox compared to the controls. Cytogenetic analysis in mothers and embryos revealed that all the tests doses produced chromosomal aberrations and micronuclei $(\mathrm{MN})$ formations in a dose dependent manner compared to the controls. These results indicate that Avelox has a maternal and embryotoxic effects on the female mice and their embryos when administered with a recommended and above the recommended dose during pregnancy.
\end{abstract}

Key words: Moxifloxacin - chromosomal aberrations - micronuclei - mice - embryos

\section{Introduction}

Antibiotics are medicines designed to treat bacterial infections. A new fluoroquinolone antibacterial for the treatment of respiratory tract infections is known as Avelox ${ }^{\circledR} \quad$ (Moxifloxacin). Moxifloxacin works Relialdy against all relevant respiratory pathogens and is characterized by its rapid efficacy, excellent tolerability and high cure rates. Patients begin to feel much better soon after starting therapy. Moreover, clinical trials involving more than 8.000 patients to date indicate that Avelox has a low propensity for the development of bacterial resistance (Minenko et al., 2004). Moxifloxacin inhibit the functionally related mammalian to poisomerase II (Tomas et al., 2004). As can sequence of these effects Fluoroquinolones have shown genotoxic effects in pro-and eulkaryotic systems. However, it has to be taken into account that several orders of magnitude higher concentrations as for gyrase are normally needed for topoisomerase-11inhibition (Drago et al., 2004).
Based on their specific mode of action, enzyme, inhibition, and in contrast to chemical mutagens which directly interact with DNA, no-effect levels can be defined for Fluoroquinolones which act by enzyme inhibition if no enzyme inhibition take place no genotoxic effect can be induced (Mah, 2004).

The safe use of Moxifloxacin in human pregnancy has not been established. Therefore, we study the effect of Avelox ${ }^{\circledR}$ (Moxifloxacin) on the pregnant females and embryos (in vivo) if given orally to mice during the pregnancy.

\section{Materials and Methods}

\section{Test drug:}

Moxifloxacin (Avelox) was provided from Bayer Laboratories (Moxifloxacin hydrochloride) is a synthetic broad spectrum antibacterial agent) and is available as Avelox Tablets for oral administration and as Avelox I.V. for Intravenous administration. 
Moxifloxacin, afluoroquinolone, is available as the monohydrochloride salt of 1-cyclopropy 1-7[s,s]- 2,8-diazabicy C10 [3.30] non-8-yl]-6-fluoro-slightly yellow to yellow crystalline substance with a molecular weight of 437.9. Its empirical formula is $\mathrm{C}_{21} \mathrm{H}_{24} \mathrm{FN}_{3} \mathrm{O}_{4}$.

\section{Animals and Treatments:}

Young adult male and virgin female mice of about 8-12 weeks of age were used and housed five or six per cage in a $12 \mathrm{~h}$ light: $12 \mathrm{~h}$ dark cycle with food and drinking water available add libitum.

The recommended dose for Moxifloxacin is $400 \mathrm{mg}$ once daily. $250 \mathrm{ml}$ solution contain $336.8 \mathrm{mg}$ Moxifloxacin hydrochloride, equivalent to $400 \mathrm{mg}$ Moxifloxacin. The adjustment of dosage is required for mice. Three groups of pregnant females were treated orally with $0.5 \mathrm{ml}$ of Avelox, equivalent to 8.7, 17 and 26 $\mathrm{mg} / \mathrm{kg} /$ day Moxifloxacin. Females were mated with males 3:1 per cage the day on which the vaginal plug appears positive was considered 1 day of pregnancy. Immediately on 1 day of pregnancy females were treated with three doses of Moxifloxacin the lowest dose $8.7 \mathrm{mg} / \mathrm{kg}$ used correspond to the recommended dose of human and the two other doses 17 and $26 \mathrm{mg} / \mathrm{kg}$ correspond to 2 and 3 times the recommended dose respectively. Control females were treated with $0.5 \mathrm{ml} / \mathrm{kgof}$ saline. The treatments of Moxifloxacin with doses of $(8.7,17$ and $26 \mathrm{mg}$ ) once daily from days 1 to 17 of gestation. The general behaviour of females was observed every day. All females were sacrificed on day 18 of gestation. The uterus was opened and the number of live fetuses and dead fetuses were recorded. Live fetuses were examined for external malformations. Part of fetuses from each female were preserved in $95 \%$ ethanol for subsequent skeletal malformations and developmental toxicity. The remaining fetuses were used for cytogenetic analysis (micronucleus assay and chromosomal aberrations).

Micronucleus assay: (in bone marrow cells):

The animals were sacrificed by cervical dislocation. For each treatment 3-4 animals were used in different groups. Bone marrow smears and staining were done following the method of (Schmid 1976) with slight modifications. Briefly, both the femora were removed and the bone marrow was flushed out into a centrifuge tube with $1 \%$ sodium citrate solution from syringe. The bone marrow cells were dispersed by gentle pipetting and collected by centrifugation at $1000 \mathrm{rpm}$ for $5 \mathrm{~min}$ at $4^{\circ} \mathrm{C}$. The cell pellet was resuspended in a small volume of 5\% fetal calf aserum. Drop of this suspension was smeared on a clean slide, air-dried, fixed in absolute methanol for $15 \mathrm{~min}$ and stained the following day with Giemsa stain. One thousand of polychromatic erythrocytes (PCEs immature erythrocytes) normochromatic erythrocytes (NCEs, mature erythrocytes) and immature white cells (reddish blue) were analysed for the presence of micronuclei $(\mathrm{MN})$.

Micronucleus assay: (in embryonic cells):

On day 18 of gestation embryos were taken and a small volume of blood from the embryo tail was resuspended in a small volume of $5 \%$ fetal calf serum. A drop of this suspension was smeared on a clean slide, air dried, fixed in absolute methanol for $15 \mathrm{~min}$ and stained with Giemsa stain. The frequency of micronuclei in embryos were analyzed according to the method of (Schmid 1976).

\section{Chromosomal preparation (in bone marrow):}

Animals were injected i.p. with 0.2 $\mathrm{ml}$ colchinicne $90 \mathrm{~min}$ before sacrifice, which occurred $24 \mathrm{~h}$ after treatment. Bone marrow preparations for the chromosome aberra-tions in metaphase cells were obtained by the technique of Yosida et al (1971) only well-spread metaphases were analyzed in order to determine the frequencies of chromosomal aberrations. 50-spread metaphases per animal were analyzed.

\section{Chromosomal preparation (in embryos): \\ On day 18 of gestation embryos} were taken and minced in $5 \mathrm{ml}$ T.C.M. media and centrifuged at 1000 r.p.m. for 5 


\section{Hanaa M. Roshdy}

min. $2 \mathrm{mM}$ of colchicines was added to each tube. After $90 \mathrm{~min}$ tubes were taken and centrifuged for 5min. Embryonic cell preparations for the chromosome aberrations in metaphase cells were obtained by the technique of (Romagnano et al 1986). Spread metaphases were analyzed in order to determine the types of chromosomal aberrations. 50-spread metaphases per embryo were analyzed.

\section{Statistical Analysis:}

The incidences of resorption, skeletal variation, delayed ossification of fetuses between experimental and control values were calculated non-parametrically using wilcoxon's rank sum test (Siegal, 1956).

The data of chromosomal aberrations in the females and embryos were subjected to analysis of variance (ANOVA) according to snedecor and Cochran (1990). Least significant differences were used compare between means according to Waller and Duncan (1969) at probability 5\%. The data of micronucleus tests were expressed as percentage.

\section{Results}

\section{Reproductive and foetal effects:}

There were treatment-related effects on the number of implantations, the number of the live fetuses and the number of dead fetuses (Table 1). There was a significant dose- dependent decreases in the average fetal body weights compared to controls. There was an increase in the incidence of fetuses with external malformations between treated groups compared with the control (Table 2). Among the malformations increased in the treated groups agnothia, omphalocele and palatoschisis. The skeletal anomalies are shown in (Table 2). There was a significant dose-dependant increase in the skeletal anomalies between treated groups $(8.7,17$ and 26) respectively and control. The major skeletal anomalies observed is a verterbral anomalies and none of the fetuses showed any major skeletal malformations. However, visceral

Table (1): Reproductive and foetal effects.

\begin{tabular}{|c|c|c|c|c|}
\hline \multirow{2}{*}{ Parameters } & \multicolumn{4}{|c|}{ Daily dose of Avelox (mg/kg/b.w.) } \\
\cline { 2 - 5 } & Control & $\begin{array}{c}8.7 \\
\mathrm{mg} / \mathrm{kg}\end{array}$ & $\begin{array}{c}17 \\
\mathrm{mg} / \mathrm{kg}\end{array}$ & $\begin{array}{c}26 \\
\mathrm{mg} / \mathrm{kg}\end{array}$ \\
\hline No. of females & 20 & 20 & 20 & 20 \\
No. of pregnant females & 20 & 20 & 20 & 19 \\
No. of implantations & 220 & 215 & 212 & 198 \\
No. of live fetuses & 215 & 208 & 203 & 188 \\
$\%$ & $97.7 \%$ & $96.7 \%$ & $95.8 \%$ & $94.9 \%$ \\
No. of dead fetuses & 5 & 7 & 9 & 10 \\
$\%$ & $2.2 \%$ & $3.2 \%$ & $4.2 \%$ & $5 \%$ \\
Mean fetal weight (g) & 3.9 & 3.8 & 3.7 & 3.5 \\
\hline
\end{tabular}


Table (2): Incidence of fetal malformations and Anomalies.

\begin{tabular}{|c|c|c|c|c|}
\hline \multirow[b]{2}{*}{ Parameters } & \multicolumn{4}{|c|}{ Daily dose of Avelox (mg/kg/b.w.) } \\
\hline & Control & $\begin{array}{c}8.7 \\
\mathrm{mg} / \mathrm{kg}\end{array}$ & $\begin{array}{c}17 \\
\mathrm{mg} / \mathrm{kg}\end{array}$ & $\begin{array}{c}26 \\
\mathrm{mg} / \mathrm{kg}\end{array}$ \\
\hline $\begin{array}{l}\text { External malformation } \\
\text { Affected fetuses }\end{array}$ & $1 / 107$ & $3 / 104$ & $4 / 102$ & $5 / 94$ \\
\hline Agnothia & 0 & 1 & 2 & 2 \\
\hline Omphalocele & - & - & 1 & 2 \\
\hline Palatoschisis & 1 & 2 & 1 & 1 \\
\hline Skeletal anomalies & $5 / 107$ & $11 / 104$ & $14 / 102$ & $13 / 94$ \\
\hline Affected fetuses & & & & \\
\hline Extra ribs & 1 & 4 & 3 & 3 \\
\hline Wavy ribs & 1 & 3 & 3 & 0 \\
\hline Vertebral-anomalies & 3 & 4 & 8 & 10 \\
\hline Skeletal malformations & $0 / 107$ & $0 / 104$ & $2 / 102$ & $3 / 94$ \\
\hline Affected fetuses & & & & \\
\hline Ribs fused & 0 & 0 & 1 & 1 \\
\hline Ribs missing & 0 & 1 & 1 & 2 \\
\hline Visceral anomalies & $2 / 107$ & $4 / 104$ & $6 / 102$ & $8 / 94$ \\
\hline Affected fetuses & & & & \\
\hline Abnormal ovary & 0 & 0 & 3 & 4 \\
\hline Abnormal tests & 0 & 0 & 1 & 4 \\
\hline Enlarged ureter & 2 & 4 & 2 & 0 \\
\hline
\end{tabular}

anomalies are shown in Table (2). There was an increase in the visceral anomalies between treated groups especially Enlarged Urter. All these malformation were considered to be treatment related.

\section{Micronucleus test:}

The total number of micronuclei and the distribution of NCE in treated females and their embryos are given in table (3). Generally, in treated females and embryos with $(8.7,17$ and $26 \mathrm{mg}$ ) Avelox, an increase in the total number of micronuclei in the cells compared to the control was observed and these increases were higher in the treated female groups than in the treated embryo groups and theses increases were dose-dependent.
Chromosomal aberrations: (females and their embryos)

The results of total number of chromosomal aberrations and their types in treated females and their embryos and in a control group are given in Table (4) and (5). The total number of chromosomal aberrations (structural and numerical) was increased significantly in treated groups (females and embryos) compared with the control. These increases were higher in the groups of treated females than treated embryos. The most frequent structural aberrations among the treated groups were chromatid gaps, breaks, deletions, fragments, centric fusions and endometosis, and the most frequent numerical aberrations were aneuploidy and polyploidy. 


\section{Hanaa M. Roshdy}

Table (3): Results of micronucleus tests in mothers and embryos after mothers maternal oral administration with (Avelox)

\begin{tabular}{|c|c|c|c|c|}
\hline $\begin{array}{c}\text { Test } \\
\text { Substance }\end{array}$ & $\begin{array}{c}\text { Dose } \\
\text { (mg/kg/day) }\end{array}$ & $\begin{array}{c}\text { Number of } \\
\text { assessed } \\
\text { PCE }\end{array}$ & $\begin{array}{c}\text { NCE per } \\
1000 \text { PCE }\end{array}$ & $\begin{array}{c}\text { Frequency of } \\
\text { micronucleated } \\
\text { cells\% }\end{array}$ \\
\hline Mothers & 0 & 10000 & 450 & $45 \%$ \\
Control & 8.7 & 10000 & 500 & $50 \%$ \\
Avelox & 17 & 10000 & 720 & $72 \%$ \\
& 26 & 10000 & 800 & $80 \%$ \\
\hline Test & Dose & assessed & NCE per & Frequency of \\
Substance & PCEncleated \\
& (mg/kglday) & 1000 PCE & cells\% \\
\hline Embryos & 0 & 10000 & 400 & $40 \%$ \\
Control & 8.7 & 10000 & 430 & $43 \%$ \\
Avelox & 17 & 10000 & 550 & $55 \%$ \\
& 26 & 10000 & 620 & $62 \%$ \\
\hline
\end{tabular}

Table (4): Effect of oral administration of Avelox on pregnant females.

\begin{tabular}{|c|c|c|c|c|c|c|c|c|c|c|c|}
\hline \multirow{2}{*}{$\begin{array}{c}\text { Dose } \\
\mathrm{mg} / \mathrm{kg} / \text { day }\end{array}$} & \multicolumn{7}{|c|}{ Structural aberrations } & \multirow{2}{*}{$\begin{array}{c}\text { T.S. } \\
\text { A }\end{array}$} & \multicolumn{3}{|c|}{ Numerical aberrations } \\
\hline & $\begin{array}{c}\text { Chromatid } \\
\text { gaps }\end{array}$ & $\begin{array}{c}\text { Chromosomal } \\
\text { gaps }\end{array}$ & $\begin{array}{c}\text { Chromatid } \\
\text { breaks }\end{array}$ & Deletions & Fragments & \begin{tabular}{|l|} 
Centric \\
fusions
\end{tabular} & $\begin{array}{l}\text { Endo. } \\
\text { mitosis }\end{array}$ & & $\begin{array}{l}\text { Aneu- } \\
\text { ploidy }\end{array}$ & $\begin{array}{l}\text { Poly- } \\
\text { ploidy }\end{array}$ & $\begin{array}{c}\text { T.N. } \\
\text { A }\end{array}$ \\
\hline Control & 5.667 & 1.333 & $2.667^{B}$ & 4.333 & 4.333 & $0.000^{B}$ & 2.667 & $21.00^{C}$ & $6.333^{\mathrm{D}}$ & $3.333^{\mathrm{B}}$ & $9.667^{\mathrm{D}}$ \\
\hline \multicolumn{12}{|l|}{ Avelox } \\
\hline $8.7 \mathrm{mg} / \mathrm{kg} /$ day & 7.000 & 2.333 & $3.667^{B}$ & 4.667 & 2.667 & $1.333^{B}$ & 3.667 & $25.33^{B}$ & $7.000^{C}$ & $4.333^{A B}$ & $11.333^{C}$ \\
\hline 17 mg/kg/day & 6.000 & 0.000 & $8.667^{\mathrm{A}}$ & 6.000 & 2.667 & $3.667^{A}$ & 1.333 & $28.33^{A}$ & $9.667^{A}$ & $4.000^{\mathrm{B}}$ & $13.667^{B}$ \\
\hline $26 \mathrm{mg} / \mathrm{kg} / \mathrm{day}$ & 7.667 & 1.000 & $9.667^{\mathrm{A}}$ & 5.333 & 1.667 & $4.333^{\mathrm{A}}$ & 0.000 & $29.67^{D}$ & $10.323^{B}$ & $5.333^{\mathrm{A}}$ & $15.667^{A}$ \\
\hline
\end{tabular}

Means of different letters (A, B, C, D) in the same column are significantly different. The column without letters is not significant. 50 metaphase cells were examined from each animal.

Table (5): Effect of (Avelox) treatment on embryos at the $\mathbf{1 8}^{\text {th }}$ day of gestations.

\begin{tabular}{|c|c|c|c|c|c|c|c|c|c|c|c|}
\hline \multirow{2}{*}{$\begin{array}{l}\text { Dose } \\
\mathrm{mg} / \mathrm{kg} / \text { day }\end{array}$} & \multicolumn{7}{|c|}{ Structural aberrations } & \multirow{2}{*}{$\begin{array}{l}\text { T.S. } \\
\text { A }\end{array}$} & \multicolumn{3}{|c|}{ Numerical aberrations } \\
\hline & \begin{tabular}{|l} 
Chromatid \\
gaps
\end{tabular} & $\begin{array}{l}\begin{array}{l}\text { Chromosomal } \\
\text { gaps }\end{array} \\
\end{array}$ & \begin{tabular}{|l|}
$\begin{array}{l}\text { Chromatid } \\
\text { breaks }\end{array}$ \\
\end{tabular} & Deletions & Fragments & \begin{tabular}{|l|}
$\begin{array}{l}\text { Centric } \\
\text { fusion }\end{array}$ \\
\end{tabular} & \begin{tabular}{|l|} 
Endo. \\
mitosis
\end{tabular} & & $\begin{array}{l}\text { Aneu- } \\
\text { ploidy }\end{array}$ & \begin{tabular}{|l|}
$\begin{array}{l}\text { Poly- } \\
\text { ploidy }\end{array}$ \\
\end{tabular} & $\begin{array}{l}\text { T.N. } \\
\text { A } \\
\end{array}$ \\
\hline Control & $4.667^{B}$ & 1.667 & 4.667 & 2.000 & 3.333 & $0.000^{C}$ & $2.000^{A B}$ & $18.33^{\mathrm{D}}$ & $6.667^{B}$ & $2.333^{B}$ & $9.000^{\mathrm{B}}$ \\
\hline \multicolumn{12}{|l|}{ Avelox } \\
\hline $8.7 \mathrm{mg} / \mathrm{kg} / \mathrm{day}$ & $5.000^{B}$ & 2.333 & 5.333 & 4.333 & 2.667 & $1.333^{B C}$ & $0.333^{C}$ & $21.33^{C}$ & $8.667^{A B}$ & $4.000^{\mathrm{A}}$ & $12.67^{\mathrm{A}}$ \\
\hline 17 mg/kg/day & $7.333^{A}$ & 1.000 & 5.333 & 3.333 & 1.333 & $3.000^{B}$ & $3.000^{A}$ & $24.33^{B}$ & $10.670^{A}$ & $2.667^{B}$ & $13.33^{A}$ \\
\hline 26 mg/kg/day & $7.000^{A}$ & 1.333 & 5.333 & 4.000 & 3.000 & $5.667^{A}$ & $1.000^{\mathrm{BC}}$ & $27.33^{A}$ & $9.667^{A}$ & $4.333^{A}$ & $14.00^{C}$ \\
\hline
\end{tabular}

Means of different letters (A, B, C, D) in the same column are significantly different. The column without letters is not significant. 50 metaphase cells were examined from each animal. 


\section{Discussion}

Moxfloxacin (Avelox) is a fluoroquinolone antibacterial is which approved for the treatment of acute exacerbations of chronic bronchitis (AECB) and acute bacterial sinusitis. Moxifloxcacin has a broad spectrum of antibacterial activity, including activity against penicillin resistant Streptococcus-Pneumonia. The safe use of moxifloxacin during pregnancy for the mothers and embryos has not been established so in this study we try to evaluate the cytogenetic and developmental effects of (Avelox) on pregnant women and future embryos.

In the present study we found that treatment with moxfloacin from 1 day to 17 day of gestations with a dose of 8.7 $\mathrm{mg} / \mathrm{kg} /$ day which corresponds to the therapeutic parenteral dose of $400 \mathrm{mg}$ per day caused a slight increase in chromosomal and micronuclei in maternal bone marrow cells and in embryonic cells and also caused development toxicity in embryos. However, the treatment with a dose of $(17 \mathrm{mg} / \mathrm{kg} / \mathrm{day})$ which corresponds to $2 \mathrm{x}$ of therapeutic dose caused a highly significant increase in the chromosomal aberrations and micronuclei in the maternal bone marrow cells and also highly increases in the chromosomal aberrations and micronuclei in the embryonic cells with skeletal malformation were observed in embryos at 18 day of gestations while, the treatment with a dose of $25 \mathrm{mg} / \mathrm{kg} /$ day which corresponds to $3 \mathrm{x}$ of the therapeutic dose of (Avelox) caused a very significant increase in the frequencies of both chromosomal aberrations and micronuclei in the maternal bone marrow cells and in the embryonic cells but these increases were more frequent in the maternal cells than embryonic cells. Skeletal malformationwere highly increased in mice treated with $(26 \mathrm{mg} / \mathrm{kg} /$ day).

These results were in agreement with many reports by (Kowalski et al., 2004) who observed that in rabbits that had been treated with an intravenous dose of 20 $\mathrm{mg} / \mathrm{kg}$ skeletal malformations were observed.

Also (Mukherjee et al., 1993) observed that there was an increase in the incidence of abortions in monkeys and rabbits at human therapeutic concentrations. Recently (Ferguson, et al. 2004) published the results of an in vivo bone marrow chromosomal assay. Mice were intraperitoneally treated with $0.6,6$ and $20 \mathrm{mg} / \mathrm{kg}$ ciprofloxacin which is similar to moxifloxacin. This chromosomal aberration assay showed positive results for 6 and $20 \mathrm{mg} / \mathrm{kg}$.

However, negative results were observed in another study by (Herbold et $a l ., 2001)$ who found that ciprofloxacin had no genotoxic effects in mice and rats.

Also, negative results observed by (Ball et al., 2004) found that in rats and monkeys treated with Moxifloxacin did not show evidence of gentoxicity. Considering the above mentioned results it was shown that when moxifloxacin (Avelox) is administered during the pregnancy with a dose equal to the recommended dose of human (Avelox) caused a slight increase in the frequencies of chromosomal aberrations and micronuclei in maternal cells and embryonic cells. Also the administration of a dose above the recommended dose of human $2 \mathrm{x}$ and $3 \mathrm{x}$ respectively, has a mutagenic effects on both bone marrow cells and fetal cells. Also it has teratogenic effects and skeletal malformations to the fetuses. These increases were dose related. The significant increase in the chromosomal aberrations and in skeletal malformations can be taken as a celar indication that drugs can cross the placenta and interact with fetal DNA increasing the genetic load in future generations causing chromosomal abnormalities.

Also, from the above result we found that Moxilfoxacin affected maternal cells more than fetal cells. This may be as a result of the directional injection of the Moxifloxacin to the pregnant female during the pregnancy which reached directly to the mothers bone marrow cells and indirectly though the placenta to the fetal cells therefore, maxfloxacin is considered not to be safe for therapeutic dose and above therapeutic dose it has a mutagenic and developmental effects. Consequently, the 


\section{Hanaa M. Roshdy}

use of moxifloxacin during pregnancy is contraindicated.

\section{References}

1. Ball, P.; Stahlmann, R. and Kubin, R.: Safety profile of oral and intravenous moxifloxacin cumulative data from clinical trials and postmarketing studies. 2004 Clin Ther.; 26(7): 940-950.

2. Drago, L.; Bevaccli, E. and Gismando, Mr.: Effect of moxifloxacin on bacterial pathogenicity factors in comparison with amoxicillin clarithromycin and ceftriaxone. 2004 J. Chemother, 16(1): 30-37.

3. Freguson, B.J.; Guzzetta, R.U. and Spector, S.L.: Efficacy and safety of oral telithromycing oncedaily for 5 days versus moxifloxacine one daily for 10 days in the treatment of acute bacterial Rhinosinsitis. 2004 Otalaryngo Head Nechsurg.; 131(3): 207-214.

4. Herbold, A.; Susanne, Y. and Hans, J.A.: Ciprofloxacin: in vivo genotoxicity studies. 2001 Mut. Research 193-205.

5. Kowalski, R.P.; Ronanowski, E.G. and Mah, F.S.: Topical prophylaxis with moxifloxacin prevents endophthalmitis in a rabbit model Am. 2004 J. Opthalmo L., 138(1): 33-37.

6. Mah, F.S. Fonth: Generation fluoroquinolones: a new topical agents in the war on ocular bacterial infections curropin opthalmol 2004: 15(4) 316-320.
7. Minenko, S.V.; Dmitrieva, W.V.; Zhukow, W.V. and Ptnshkin, V.V.: Efficacy of moxiflexacin (Avelox) in prophylaxis of infection in patients with profound mentropenia; 2004 Antibiot Khimioter, 49(3): 26-31.

8. Mukherjee, A.; Sen, S. and Agarwal, K.: Ciprofloxaacin: Mammalian DNA topoisomerase type-11 poisonin vivo. 1993, Mut. Res.; 301: 87-92.

9. Romagnano, A.; Richer, C.L. and Perrone, M.A.: A direct technique for the preparation of chromosomes from early equine embryos. 1986, Can. J. Gent. Cytol., 27: 365-369.

10. Schmid, W.: The micronucleus test for cytogenetic analysis 1976, Mut. Res. 4: 3153.

11. Siegal, $\mathbf{S}$. Non parametric Statistics for the Behavioural sciences. 1956 Mc Graw-Hill, New York, pp. 116-127.

12. Snedecor, G.W. and Cochran, W.G.: Statistical methods, $9^{\text {th }}$ ed. Lowa Stae Unive 1990. Press, Lova, USA.

13. Tomas, L.; Alvarez, M. and Saavedra, E.: In vitro activity of moxifloxacin compared to isolated from atrogenic oral bacteremia in Spain. 2004 Oral Microbial Immunol. 331-335.

14. Waller, A. and Duncan, D.B. Multiple Range and multiple test 1969. Bionetries, 11: 1-24.

15. Yosida, T.H.; Truchiya, $K$ and Moiwaki, K.: Frequency of chromosome polymorphism of Rattus rattus. 1971 Chromosoma 30-33.

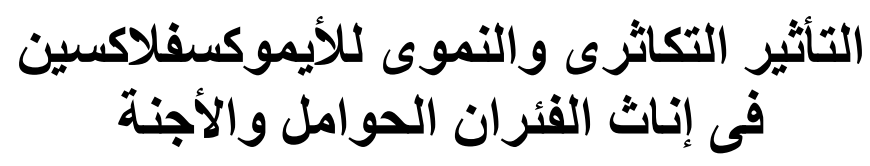


قسم بيولوجيا الخلية المركز القومى للبحوث ــ الدقى ــ القاهرة

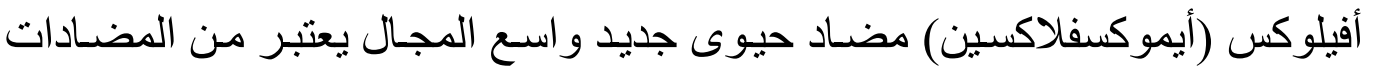

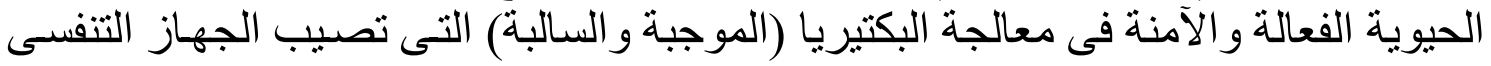

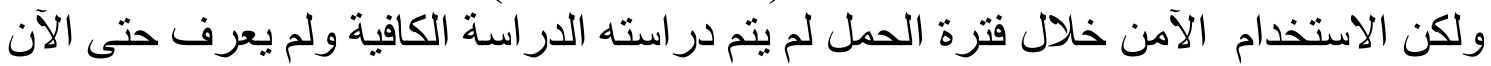

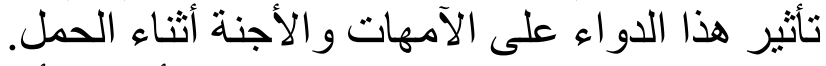

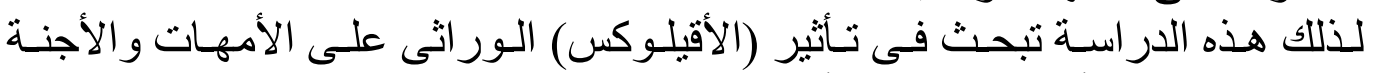

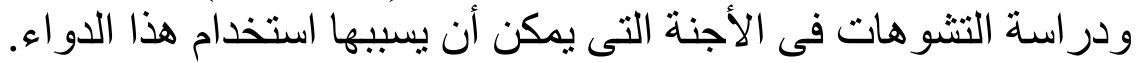

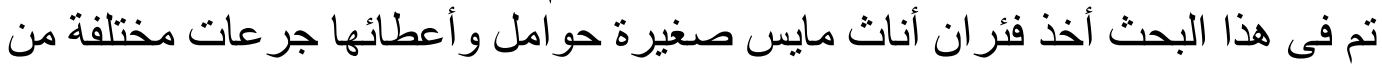

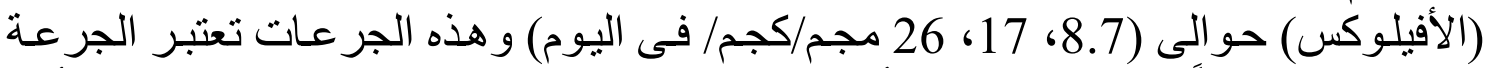

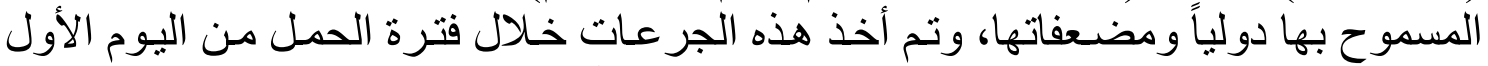

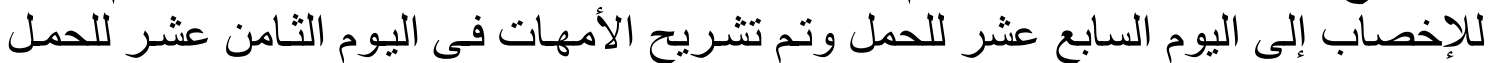

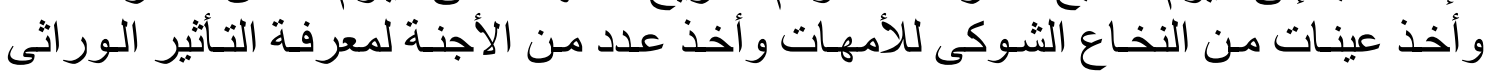
و المورفولجى للاخو اءوناء.

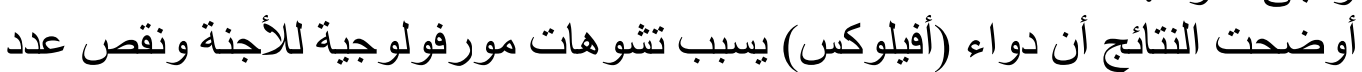

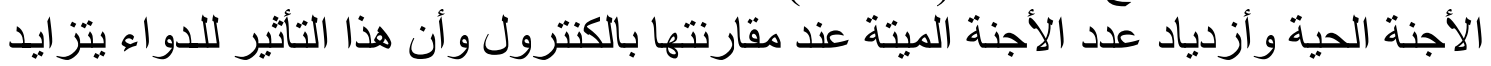

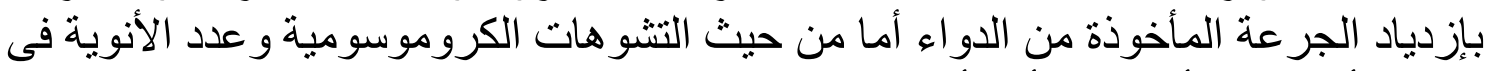

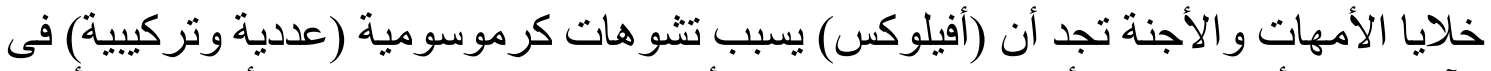

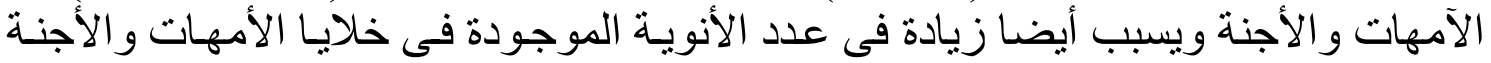

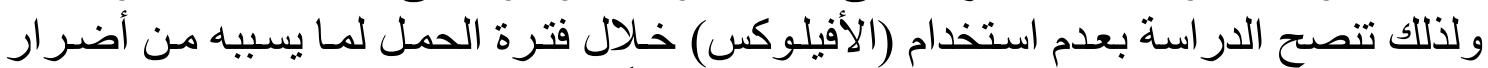
على الأم و الجنين حتى فى الجى بعدم الجنة المسموح بها دولياً. 